\title{
Are IGF-I, thyroid hormone and metabolite concentrations in calf plasma associated with growth rate, sex and age?
}

\author{
A.V. Sirotkin' , M. Svetlanská, A. Sommer, A.V. Makarevich, \\ J. Szakács and M. Poláciková
}

Research Institute of Animal Production

Hohovská 2, 94992 Nitra, Slovakia

(Received 30 October 2001; revised version 4 March 2002; accepted 9 May 2002)

\begin{abstract}
The aims of our experiments were (1) to study age-dependent changes in bovine plasma concentrations of insulin-like growth factor I (IGF-I), thyroid hormones (T3, T4), some metabolites (glucose, triglycerides, ketone bodies), calcium, phosphorus and sodium, and (2) to determine whether plasma concentrations of these substances are associated with individual and sex-dependent differences in the growth rates of calves.

Eight male and 8 female calves were weighed at the beginning and at the end of the expcriment and daily gain and feed consumption (dry matter, crude protein, PDIN and NEL per kg daily gain) were determined. Plasma concentrations of IGF..I, T3, T4, glucose, triglycerides, ketone bodies, calcium, phosphorus and sodium were measured in calves at $2,4,6,8,10$ and 12 weeks of age. There were significant age-dependent increases in the plasma concentrations of IGF-I and glucose. Males had a significantly higher daily gain and lower feed consumption than females, but no sex-dependent differences in plasma constituents were detected. In both sexes, daily gain was positively correlated with plasma IGF-I (coefficients of correlation $r=0.630$ in females and $r=0.614$ in males) and glucose ( $r=0.496$ and 0.427 , respectively) concentrations, but not with other substances.

Our observations show that there are age-dependent changes in IGF-J and glucose concentrations (but not in those of other substances), and that IGF-1 and glucose, in contrast with other substances, may be indicators or regulators of individual growth rates.
\end{abstract}

KEY WORDS: IGF-I, IGFBP-3, T3, T4, glucose, triglycerides, ketone bodies, $\mathrm{Ca}$, P, $\mathrm{Na}$, calf, sex, age

${ }^{1}$ Corresponding author 


\section{INTRODUCTION}

Understanding the regulation of farm animal growth and meat production has both biological and economical importance. Animal growth is known to be dependent on age, sex and nutrition, but the substances that mediate these effects are not completely understood.

One such mediator may be insulin-like growth factor I (IGF-I). There is evidence that it plays an important role in the control of reproduction, metabolism and growth in farm animals. The concentration of IGF-I in bovine plasma increases during puberty (Ronge and Blum; 1989; Plouzck and Trenkle, 1991; Schlee et al., 1994b; Egli and Blum, 1998), correlates positively with plasma LH and progesterone concentrations and oocyte quality, and decreases during anoestrus induced by undernutrition (Richards et al., 1995; Armstrong et al., 2001). IGF-I can stimulate the differentiation and function of gonadal cells, while gonadal steroid hormones augment IGF-I production (Lec et al., 1991; Plouzek and Trenkle, 1991; Richards et al., 1995; Spicer and Echternkamp, 1995; Armstrong and Webb, 1997; Simpson et al., 1997). Male cattle have higher plasma IGF-I, androgen and total estrogen concentrations (Plouzek and Trenkle, 1991; Egli and Blum, 1998) compared with females. Androgen, and to a lesser extent estrogen, can augment plasma IGF-I concentrations (Plouzek and Trenkle, 1991; Aldrich ct al., 1996; Simpson et al., 1997). These observations suggest that the increased growth rate of males may be induced by a sex-dependent steroid/IGF-I axis.

IGF-I mediates the influence of nutrition on bovine growth and metabolism. Increased feed intake stimulates release of IGF-I (Richards et al., 1995, Barash et al., 1998, Gerrits et al., 1998; Hammon et al., 2000; Armstrong et al., 2001), which in turn promotes anabolic processes, growth and meat production (Florini et al., 1996; Hill et al., 1999). Bovine plasma IGF-I concentration increases during postnatal ontogenesis simultaneously with increases in body mass (Ronge and Blum, 1989; Schlce et al., 1994b; Egli and Blum, 1998; Blum and Hammon, 1999). Several authors have observed that higher daily weight gain in bulls is associated with higher IGF-I (Anderson et al., 1988; Istasse et al., 1990; Schlee et al., 1994b; Richards et al., 1995; Yelich et al., 1996; Barash et al., 1998) and glucose (Richards et al., 1995) concentrations, although other authors did not report such correlations (Ronge and Blum, 1989; Hall et al., 1995). Thus, the sexual and individual differences in bovine growth and meat production may be principally due to effects of male and female steroid hormones and nutrition on IGF-I. However, because the available experimental data is contradictory, this hypothesis requires further study.

The involvement of the thyroid hormones, triiodothyronine (T3) and thyroxine (T4), in controlling individual sex-and nutrition-dependent differences in growth and metabolism is less documented. Reports suggest that male cattle have lower thyroid hormone levels than females (Egli and Blum, 1998) and castrates (Plouzek 
and Trenkle, 1991), and that feed intake causes an increase in the concentration of this hormone (Richards et al., 1995; Barash et al., 1998; Gerrits et al., 1998). There is no uniform view on age-related changes in thyroid hormones: both increased (Anderson et al., 1988; Ronge and Blum, 1989; Tancin ct al., 1994) and decreased (Egli and Blum, 1998; Hammon and Blum, 1998) plasma thyroid hormone levels during growth in calves have been reported. Thus, these relationships also require further study.

Production of the nutrition- and sex-related substances mentioned above may be correlated with changes in plasma concentrations of the metabolites of carbohydrates, peptides and fats. It was reported that the bovine plasma IGF-I concentration correlates positively with plasma glucose (Richards et al., 1995; Hammon et al., 2000), but injections of IGF-I analogue did not affect plasma nonesterified fatty acid concentrations (Hammon and Blum, 1998). Females have higher plasma lipoprotein and cholesterol concentrations than males (Ochoa and Marchello, 1991) and estradiol treatment was found to decrease urea nitrogen and increase blood glucose in cattle (Simpson et al., 1997). Protein intake augments glucose, triglyceride, but not nonesterified fatty acid levels in bovine plasma (Putnam and Varga, 1998; Blum and Hammon, 1999; Hammon et al., 2000; Rauprich et al., 2000). The age-dependent decrease in plasma glucose and increase in plasma cholesterol, calcium, and phosphorus concentrations (which may be due to age-dependent changes in nutrition) are not associated with substantial alterations in non-esterified fatty acid and triglyceride concentrations (Tancin et al., 1994; Hugi and Blum, 1997; Kume et al., 1998; Blum and Hammon, 1999). Thus, the effects of nutrition, IGF-I and sex hormones on bovine growth may be associated with age-dependent changes in plasma metabolite concentrations but the evidence is too limited to show clear interrelationships and further studies are required.

The first aim of our experiments was to study changes in bovine plasma concentrations of IGF-I, T3, T4, specific metabolites (glucose, triglycerides, ketone bodies), as well as calcium, phosphorus and sodium in relation to cattle age. The second aim was to determine whether these substances may be responsible for individual and sexual differences in calf growth rate.

\section{MATERIAL AND METHODS}

\section{Animals}

The experiment was performed in February-May 1999. Eight male and eight female calves, randomly selected, of a Holstein (Black-and-White) breed were housed under standard conditions at the experimental farm of the Research Institute of Animal Production, Nitra. After weaning at 12 weeks of age, calves were 
fed ad libitum 3 times a day with a standard ration (lucerne hay and concentrates, including milk concentrates but without bacteriostatics or growth stimulators; Dairy Industry Research Institute, Žilina, Slovakia). Animals were weighed regularly between 2 and 12 weeks of age. Feed consumption: dry matter, crude protein, protein digested in the intestines (PDIN) and net energy of lactation (NEL) per kg weight gain, were determined as described previously (Svetlanska et al., 1999). Once every two weeks (every second Monday, $4 \mathrm{~h}$ after the first feeding) from 2 to 12 weeks of age, blood was sampled $(10 \mathrm{ml})$ from the jugular vein by a $10-\mathrm{ml}$ syringe into glass tubes containing $0.1 \mathrm{ml} 4 \%$ sodium citrate. Plasma was separated by centrifugation $(2000 \mathrm{~g})$ and immediately frozen at $-18^{\circ} \mathrm{C}$.

\section{Radioimmunoassay}

Concentrations of hormones, growth factors and growth factor binding protein were determined in duplicate samples of plasma (25-100 ul), without extraction except for IGF-I. IGF-I, T3 and T4 were assayed using commercial RIA/IRMA kits from DSL (Webster, Texas, USA). All assays were previously validated for bovine plasma (Table 1).

Assay of metabolites

Concentrations of glucose, triglycerides and phosphorus in blood plasma were measured in triplicate by colorimetric methods using a Spckol 11 photocolorimeter

TABLE 1

Characteristics of immunoassays

\begin{tabular}{|c|c|c|c|c|}
\hline \multirow[t]{2}{*}{ Assay } & \multirow{2}{*}{$\begin{array}{l}\text { Specificity (cross-reactivity } \\
\text { of antiscrum) }\end{array}$} & \multirow[t]{2}{*}{ Sensitivity } & \multicolumn{2}{|c|}{$\begin{array}{l}\text { Coefficient of } \\
\text { variation, } \%\end{array}$} \\
\hline & & & $\begin{array}{l}\text { Intra- } \\
\text { assay }\end{array}$ & $\begin{array}{l}\text { Inter- } \\
\text { assay }\end{array}$ \\
\hline IGF-I & $\begin{array}{l}<0.01 \% \text { to IGF-II, } \\
\text { insulin, proinsulin, oxytocin, } \\
\text { somatostatin, bGH }\end{array}$ & $0.3 \mathrm{ng} / \mathrm{ml}$ & $<3.4$ & $<8.2$ \\
\hline $\mathrm{T} 3$ & $\begin{array}{l}<0.003 \text { to } \mathrm{T} 4 \\
<1.76 \text { to triodothyracetic acid } \\
<0.002 \text { to dijodothyronine, } \\
\text { monoiodothyronine, diiodotyrosine }\end{array}$ & $0.43 \mathrm{ng} / \mathrm{ml}$ & $<6.5$ & $<6.0$ \\
\hline $\mathrm{T} 4$ & $\begin{array}{l}<0.091 \text { to } \mathrm{T} 3 \\
<1.13 \text { to triodothyracetic acid } \\
<0.003 \text { to diiodothyronine, } \\
\text { monoiodothyronine, diiodotyrosine }\end{array}$ & $40 \mathrm{ng} / \mathrm{ml}$ & $<5.1$ & $<7.4$ \\
\hline
\end{tabular}


(Carl Zeiss, Jena, Germany) and commercial GLU 250 E, TG 50 and P80 kits from Lachema (Brno, Czech Republic). Ketone bodies were determined by gas chromatography (HP5830A, Hewlett Packard, Palo Alto, CA, USA) according to Hradecky and Jogos (1978). Calcium and sodium ion concentrations were determined in triplicate by atomic absorption spectrometry (SOLKAR 939, UNICAM, Cambridge, UK).

\section{Statistical analysis}

Each experimental group comprised 8 animals. Differences between the groups (concurrent samples from males and females or samples collected during different bleeds) were determined by ANOVA followed by Duncan's multiple range test, using the Microsoft Excel 7 or SigmaPlot computer programs. Correlations between the indices were calculated using Excel 7. Differences between the groups with $\mathrm{P}<0.05$ were considered significant.

\section{RESULTS}

Weighing before- and at the end of experiment showed significant age-dependent increases in body mass in all studied animals. Separate analysis of data for female and male calves before the experiment showed no significant difference although average body mass in females tended to be higher than in males. At the end of experiment, males tended to be heavier than females, although the differences were again statistically insignificant. In contrast to live body weight, male calves had a significantly higher $(\mathrm{P}<0.01)$ daily gain than females over the course of the experiment. The increase was accompanied by a significant decrease in all indices of feed consumption (dry matter, crude protein, PDIN and NEL) measured relative to daily gain (Table 2 ).

Plasma IGF-I concentrations (Figure 1a) showed no substantial age-dependent changes, in either male or female calves, from 2 to 8 weeks of age. Thereafter ( 10 and 12 weeks of age) plasma IGF-I rose significantly in both sexes. No significant sex-dependent differences in IGF-I were found during the experiment. No statistically significant age- or sex-dependent differences in plasma T3 (Figure lb) and T4 (Figure 1c) concentrations were found. The maximal levels of these hormones were detected at 2 weeks of age.

There was a gradual age-dependent increase in plasma glucose concentrations. This was significant in females but insignificant in males because of a larger variance. No other differences in glucose concentration between males and females were found (Figure 1d). Concentrations of triglyceride, ketone bodies, calcium, phosphorus and sodium showed no significant effects of sex or age. 
TABLE 2

Growth rate and feed consumption in female and male calves over the course of experiment

\begin{tabular}{lccc}
\hline Characteristic & Female & Male & $\begin{array}{c}\text { Differences between } \\
\text { sexes }\end{array}$ \\
\hline $\begin{array}{l}\text { Initial body mass } \\
(2 \text { weeks of age), kg }\end{array}$ & $50.43 \pm 4.14$ & $47.00 \pm 5.73^{\prime}$ & n.s. \\
Final body mass & & & \\
(12 weeks of age), kg & $107.71 \pm 6.02$ & $108.29 \pm 5.39$ & n.s. \\
Average daily gain, & & & \\
kg/day & $0.72 \pm 0.03$ & $0.80 \pm 0.03$ & $\mathrm{P}<0.01$ \\
& & & \\
Consumption per $1 \mathrm{~kg}$ of daily gain & & & $\mathrm{P}<0.01$ \\
dry matter, g & $2741 \pm 538$ & $2493 \pm 449$ & $\mathrm{P}<0.01$ \\
crude protein, g & $619 \pm 123$ & $563 \pm 102$ & $\mathrm{P}<0.01$ \\
PDIN, g & $391 \pm 78$ & $355 \pm 66$ & $\mathrm{P}<0.01$ \\
NEL, MJ & $22.1+4.2$ & $19.9+3.3$ & \\
\hline
\end{tabular}

+ S.E.D.

n.s. - not significant, $P<0.01$ - significant differences between the sexes

Daily weight gain was significantly correlated with plasma IGF-I $(r=0.630$ in females and 0.614 in males) and glucose concentrations ( $r=0.496$ and 0.427 , respectively) but not with other metabolites (Table 3).

\section{DISCUSSION}

Our observation of an age-dependent increase in plasma IGF-I concentration confirms data obtained by other authors on calves of this breed (Ronge and Blum, 1989; Plouzek and Trenkle, 1991; Schlee et al., 1994b; Egli and Blum, 1998). This suggests an involvement of IGF-I in the control of growth and development in calves. The absence of significant age-related changes in plasma T3 and T4 during the experiment is not consistent with previous reports where increases (Anderson et al., 1988; Ronge and Blum, 1989; Tancin et al., 1994) or decreases (Egli and Blum, 1998; Hammon and Blum. 1998) were observed. The increase in plasma glucose concentrations observed in our experiment is contrary to the decrease reported previously (Tancin et al., 1994; Hugi and Blum, 1997; Blum and Hammon, 1999). Moreover, the stable concentrations of plasma calcium, phosphorus and sodium during our experiment do not correspond with an earlier report of agedependent decreases of these ions (Kume et al., 1998). The stable concentrations 


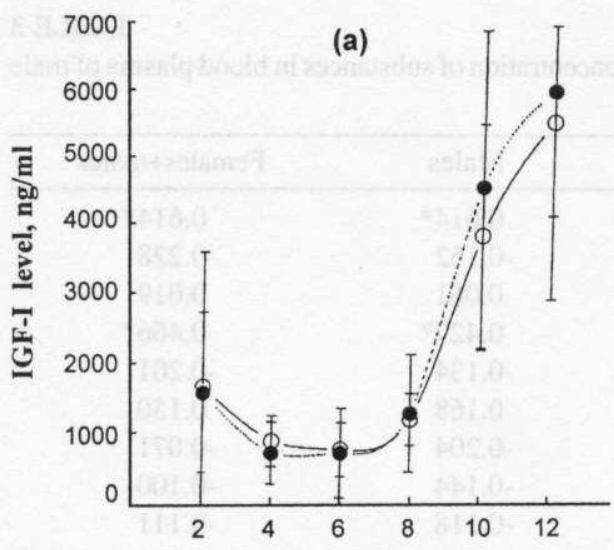

Age, weeks
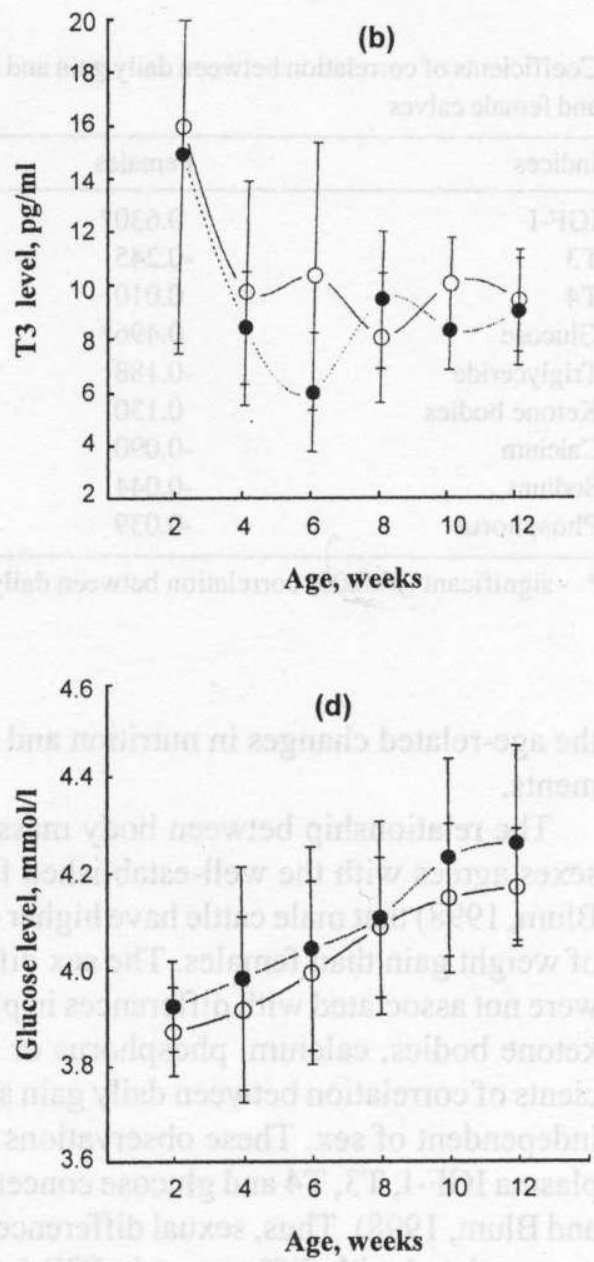

Figure 1. The age-dependent changes of substances in plasma of female (white circles) and male (black circles) calves: IGF-I (a), T3 (b), T4 (c) and glucose (d). Values are means + S.E.D.

of metabolites of fat (plasma triglycerides) do agree with the observations of other authors (Hugi and Blum, 1997; Blum and Hammon, 1999).

These discrepancies between observations, taken together with the well-known influence of nutrition and stress on thyroid hormone (Richards et al., 1995; Barash et al., 1998; Gerrits et al., 1998) and metabolic indices (Tancin et al., 1994; Richards et al., 1995; Hugi and Blum, 1997; Simpson et al., 1997; Kume et al., 1998; Putnam and Varga, 1998) support the hypothesis (Blum and Hammon, 1999), that plasma thyroid hormone and metabolite concentrations depend not on age per se, but on 
TABLE 3

Coefficients of correlation between daily gain and concentration of substances in blood plasma of male and female calves

\begin{tabular}{lccc}
\hline Indices & Females & Males & Females+males \\
\hline IGF-I & $0.630^{*}$ & $0.614^{*}$ & $0.614^{*}$ \\
T3 & -0.245 & -0.162 & -0.228 \\
T4 & 0.010 & 0.061 & 0.019 \\
Glucose & $0.496^{*}$ & $0.427^{*}$ & $0.466^{*}$ \\
Triglyceride & -0.188 & -0.134 & -0.201 \\
Ketonc bodies & 0.130 & 0.168 & 0.150 \\
Calcium & -0.090 & -0.204 & -0.071 \\
Sodium & -0.044 & -0.144 & -0.100 \\
Phosphorus & -0.039 & -0.118 & -0.111 \\
\hline
\end{tabular}

* - significant $(\mathrm{P}<0.05)$ correlation between daily gain and plasma concentration of substance

the age-related changes in nutrition and other conditions during particular experiments.

The relationship between body mass and daily gain in animals from different sexes agrees with the well-established fact (Plouzek and Trenkle, 1991; Egli and Blum, 1998) that male cattle have higher daily gain and better feed utilization per $\mathrm{kg}$ of weight gain than females. The sex differences in daily gain and feed utilization were not associated with differences in plasma IGF-I, T3, T4, glucose, triglyceride, ketone bodies, calcium, phosphorus or sodium content. Furthermore, the coefficients of correlation between daily gain and plasma metabolite concentrations were independent of sex. These observations contradict reports that males have higher plasma IGF-I, T3, T4 and glucose concentrations (Plouzek and Trenkle, 1991; Egli and Blum, 1998). Thus, sexual differences in daily gain are probably not induced by or associated with differences in IGF-I, T3 and T4, and they are not accompanied by differences in plasma concentrations of glucose, triglycerides, ketone bodies, calcium, phosphorus and sodium. Although sex hormones can affect plasma IGF-I (Plouzek and Trenkle, 1991; Aldrich et al., 1996; Simpson et al., 1997) and glucose (Simpson et al., 1997), our observations showed that sex is probably not the main factor determining the plasma concentration of these substances and, furthermore, that sex differences in growth and feed consumption rates are not due to the differences in IGF-I, T3, T4, glucose, triglycerides, ketone bodies, calcium, phosphorus or sodium. The mechanism by which sex influences bovine growth therefore remains unknown. Direct effects of steroid hormones on cell proliferation, without effect on potential mediators such as growth factors, thyroid hormones and metabolites, are possible, as is an effect of steroids on receptor and post receptor events. 
The significant correlations between daily gain, plasma IGF-I and glucose concentration correspond to reports describing an association between bovine growth rate, plasma IGF-I (Anderson et al., 1988; Istasse et al., 1990; Schlee et al., 1994b; Richards et al., 1995; Yelich et al., 1996; Barash et al., 1998) and plasma glucose (Richards et al., 1995), and of a lack of influence of IGF-I on thyroid hormone concentrations and fat metabolism (Hammon and Blum,1998). Our data did not confirm reports in which any correlation between growth rate and plasma IGF-I concentration were found (Ronge and Blum, 1989; Hall et al., 1995) but do support the hypothesis (Richards et al., 1995; Florini et al., 1996; Blum and Hammon, 1999; Hill et al., 1999) that IGF-I may be an important regulator of bovine growth and of related plasma glucose concentrations.

In summary, our observations on calves show that (1) there are age-dependent changes in IGF-I and glucose (but not in T3, T4, triglyceride, ketone bodies, calcium, phosphorus and sodium) concentrations, (2) IGF-l and glucose, in contrast to other substances, may be indicators and regulators of individual bovine growth rate.

\section{ACKNOWLEDGEMENTS}

The authors are indebted to Prof. J. Kováčik (Slovakian University of Agriculture, Nitra), Ing. S. Čerešnáková, Mrs. T. Cívaňová, K. Tothová, M. Petrikovičová and $M$. Blahová for technical assistance during the conduction of these experiments and analysis of samples.

\section{REFERENCES}

Aldrich S.L., Berger L.L., Kesler D.J., Nash T.G., McCusker R.H. Jr., 1996. Effect of prenatal androgenization and postnatal steroid treatment of growth hormone, insulin-like growth factor I and II, insulin, thyroxine, and triiodothyronine concentrations in beef heifers. J. Anim. Sci. 74, 420-428

Anderson P.T., Bergen W.G., Merkel R.A., Enright W.J., Zinn S.A., Refsal K.R., Hawkins D.R., 1988. The relationship between composition of gain and circulating hormones in growing beef bulls fed threc dietary crude protein concentrations. J. Anim. Sci. 66, 3059-3067

Armstrong D.G., Webb R., 1997. Ovarian follicular dominance: the role of intraovarian growth factors and novel proteins. Rev. Reprod. 2, 139-146

Armstrong D.G., McEvoy T.G., Baxter G., Robinson J.J., Hogg C.O., Woad K.J., Webb R., Sinclair K.D., 2001. Effect of dietary energy and protein on bovine follicular dynamics and embryo production in vitro: associations with ovarian insulin-like growth factor system. Biol, Reprod. $64,1624-1632$

Barash H., Aharoni Y., Brosh A., Holzer Z., 1999. Effect of low energy diets followed by a compensatory dict on body weight gain and plasma hormone concentrations in bull calves. J. Dairy Sci. $81,250-254$ 


\section{CORRELATION BETWEEN PLASMA METABOLITES AND GROWTH OF CALVES}

Blum J.W., Hammon H., 1999. Endocrine and metabolic aspects in milk-fed calves. Domest. Anim. Endocrinol. 17,219-230

Egli C.P., Blum J.W., 1998. Clinical, hacmatological, metabolic and endocrine traits during the first three months of life of suckling Simmentaler calves held in a cow-calf operation. Zbl. Vetmed. A $45,99-118$

Florini J.R., Ewton D.Z., Coolican S.A., 1996.Growth hormone and insulin-like growth factor system in myogenesis. Endocrine Rev. 17, 481-517

Gerrits W.J.J., Decuypre E., Verstegen M.W.A., Karabinas V., 1998. Effect of protein and proteinfree energy intake on plasma concentrations of instilin-like growth factor I and thyroid hormones in preruminant calves. J. Anim. Sci. 76, 1356-1363

Hall J.B., Staigniller R.B., Bellows R.A., Short R.E., Moseley W.M., Bellows S.E., 1995. Body composition and metabolic profiles associated with puberty in beef heifers. J. Anim. Sci. 73, $3409-3420$.

Hammon H., Blum J.W., 1998. Endocrine and metabolic changes in neonatal calves in response to growth hormone and long-R3-insulin-like growth factor-I administration. Biol. Neonate 73, 121-128

Hammon H.M., Zanker I.A., Blum J.W., 2000. Delayed colostrum feeding affects IGF-I and insulin plasma concentrations in neonatal calves. J. Dairy Sci. 83, 85-92

Hill R.A., Hunter R.A., Lindsay D.B., Owens P.C.. 1999. Action of long (R3)-insulin-like growth factor-1 on protein metabolism in beef heifers. Domest. Anim. Endocrinol. 16. 219-229

Hradecky P., Jagos P., 1978. Gas chromatographic head-space analysis of clinically interesting ketone bodies. J. Chromatogr. 146, 327-332

Hugi D., Blum J.W., 1997. Changes of blood metabolites and hormones in brceding calves associated with weaning. Zbl. Vetmed. 44, 99-108

Istasse L., Van Eenaeme C., Evrard P., Gabriel A., Baldwin P., Maghuin-Rogister G., Bienfait J.M., 1990. Animal performance, plasna hormones and metabolites in Holstein and Belgian Blue growing-fattening bults. J. Anim. Sci. 68, 2666-2673

Kume S., Toharmat T., Kobayashi A., 1998. Effect of restricted feed intake of dams and heat stress on mineral status of newborn calves. J. Dairy Sci. 81, 1581-1590

Lee C.Y., Hunt D.W., Gray S.L., Hendricks D.M., 1991. Secretory patterns of growth hormone and insulin-like growth factor- I during peripuberlal period in intact and castrated male cattle. Domest. Anim. Endocrinol. 8, 481-489

Ochoa M.F.. Marchello J.A., 1991. Bovine lipoprotein and apolipoprotein profiles as influenced by sex and growth. J. Anim. Sci. 69, 4030-4038

Plouzek C.A., Trenkle A., 1991. Insulin-like growth factor-I concentrations in plasma of intact and castrated male and female cattle at four ages. Domest. Anim. Endocrinol. 8, 73-79

Putnam D.E., Varga G.A., 1998. Protein density and its influence on metabolite concentration and nitrogen retention by Holstein cows in late gestation. J. Dairy Sci. 81, 1608-1618

Richards M.W., Spicer L.J., Wettemann R.P., 1995. Influence of diet and ambient-temperature on bovine scrum insulin-like growth factor-I and thyroxine - relationships with nonesterified fatty acids, glucose, insulin, luteinizing hormone and progesterone. Anim. Reprod. Sci. 37, 267-279

Ronge H., Blum J., 1989. Insulin-like growth factor I during growth in bulls. Reprod. Nutr. Develop. $29,105-111$

Rauprich A.B.E., Hammon H.M., Blum J.W., 2000. Influence of feeding different amounts of first colostrum on metabolic, endocrine, and health status and on growth performance in neonatal calves. J. Anim. Sci, 78, 896-908

Schlee P., Graml R., Schallenberger E., Schams D., Rottman O., Olbrich-Bludau A., Pirchner F., 1994. Growth hormone and insulin-like growth factor concentrations in bulls of various growth hormone genotypes. Theor. Appl. Genet. 88, 497-500 
Simpson R.B., Chase C.C. Jr., Spicer L.J., Carroll J.A., Hammond A.C., Welsh T.H. Jr., 1997. Effect of exogenous estradiol on plasma concentrations of somatotropin, insulin-like growth factor binding protein activity and metabolites in ovariectomized Angus and Brahman cows. Domest. Anim. Endocrinol. 14, 367-380

Spicer L.J., Echternkamp S.E., 1995. The ovarian insulin-like growth factor system with an enphasis on domestic animals. Domest. Anim. Endocrinol. 12, 223-245

Svetlanská M., Sommer A., Petrikovič P., Boroš V., 1999. The effect of feeding lactic fermented products on nutrient consumption in calves until 90 days of age. Czech J. Anim. Sci. 44, 113-117

Tančin V., Brouček J., Valent M., Kováčik J., Harcek L., Mihina Š., 1994. Different nutrition of calves in relation to the concentrations of thyroid hormones and some biochemical indexes (in Czech). Živ. Vyroba 39, 961-971

Yelich J.W., Wetterman R.P., Marston T.T., Spicer L.J., 1996. Luteinizing hormone, growth hormone, insulin-like growth factor-I, insulin and metabolites before puberty in heifers fed to gain at two rates. Domest. Anim. Endocrinol. 13, 325-338.

\section{STRESZCZENIE}

Czy stężenie IGF-1, hormonów tarezycy oraz metabolitów w plazmie krwi cieląt są związane $z$ tempem wzrostu, plcią i wiekiem?

Celem doświadczeń było: (1) prześledzenie zmian zachodzących wraz z wiekiem cieląt w stężeniu w plazmic krwi czynnika insulino-podobnego I(IGF-I), hormonów tarczycy (T3, T4) oraz metabolitów (glukozy, trójglicerydów, ciał ketonowych, Ca, P i Na) oraz (2) określenie, czy stężenie tych składników w plazmic zalcży od różnic indywidualnych i płci rosnących cicląt.

Zwierzęta ważono przed i po zakończeniu doświadczenia, oznaczano przyrosty dzienne i pobranic paszy (s.m., białko ogólne, PDIN oraz NEL na przyrost kg/dzień). Stçżcnie IGF-I, T3, T4, glukozy, trójglicerydów, ciał ketonowych, Ca, P i Na oznaczano u 8 jałówek i 8 buhajków w 2, 4, 6, 8,10 i 12 tygodniu życia. Stwierdzono istotne zwiększanic stężenia tylko Tl oraz glukozy w plazmie wraz z wiekiem. Przyrosty dzienne buhajków i wykorzystanie przez nie paszy były lepsze niż u jałówck, przy czym nie stwierdzono różnic w stężeniu badanych metabolitów w plazmie krwi w zależności od płci. U cieląt obydwóch płci przyrosty dzienne były dodatnio skorelowane ze stężeniem IGF-I (współczynniki korelacji $\mathrm{r}=0,630$ u jałówek i $\mathrm{r}=0,614$ u buhajków) oraz glukozy (odpowiednio $\mathrm{r}=(0,496$ i 0,427$)$.

Autorzy stwierdzają, że (1) występują zmiany w stężeniu IGF-J i glukozy związane z wiekiem oraz, że (2) lGF-l i glukoza, w przeciwieństwie do innych metabolitów, mogą być wskaźnikami lub regulatorami tempa wzrostu u poszczcgólnych zwicrząt, a także że (3) żadna z oznaczanych substancji nie powoduje różnic w tempie wzrostu związanych z płcią cieląt. 